\title{
Sources and source strengths of volatile phenol in Jiaozhou Bay 1983
}

\author{
Dongfang Yang ${ }^{1,2,3, a}$, Xiuqin Yang ${ }^{1,}$, Yunjie $\mathrm{Wu}^{1,2}$, Sixi Zhu ${ }^{1,2}$ and \\ Fengyou Wang ${ }^{1,2, b, c}$ \\ ${ }^{1}$ Research Center for Karst Wetland Ecology, Guizhou Minzu University, Guizhou Guiyang, \\ Guizhou Guiyang, China; \\ ${ }^{2}$ College of Chemistry and Environmental Science, Guizhou Minzu University, Shanghai, 550025, \\ China; \\ ${ }^{3}$ North China Sea Environmental Monitoring Center, SOA, Qingdao 266033, China.

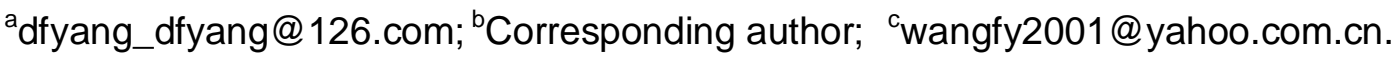

Keywords: Volatile phenol; Content; Distribution; Pollution level; Pollution source; Source strength; Jiaozhou Bay

\begin{abstract}
Based on the analysis on the content and spatio-temporal distribution of volatile phenol, this paper assessed the pollution level, pollution source and source strength of volatile phenol in Jiaozhou Bay 1983. Results showed volatile phenol contents ranged from $0.50-3.38 \mu \mathrm{g} \mathrm{L}^{-1}$ in the whole year, and were more lower than Class I for volatile phenol $\left(5.00 \mu \mathrm{g} \mathrm{L}^{-1}\right)$ in National Standard of China for Seawater Quality (GB3097-1997). There were some relative high value regions, including estuaries of the major rivers in the northeast, coastal areas in the east, north and southwest, as well as waters outside the bay mouth. The major sources of volatile phenol were stream flow, overland flow inside the bay, marine current, overland flow outside the bay and marine terminals, whose source strengths were 2.58-3.38 $\mu \mathrm{g} \mathrm{L}^{-1}, 2.25-2.60 \mu \mathrm{g} \mathrm{L}^{-1}, 2.50 \mu \mathrm{g} \mathrm{L}^{-1}, 1.90 \mu \mathrm{g} \mathrm{L}^{-1}$ and 1.75 $\mu \mathrm{g} \mathrm{L} \mathrm{L}^{-1}$, respectively. Generally speaking, Jiaozhou Bay was very slightly contaminated by volatile phenol in 1983, and the impacts from human activities were closed to sea water pollutant background.-
\end{abstract}

\section{Introduction}

Volatile phenol has been widely used in industries such as wood distillation, synthetic fiber, dyestuff, medicine, pesticide etc. A large amount of volatile phenol-containing waste water was generated during the production process. Due to the lag of water pollution treatment to the emission load, and the high toxicity, volatile phenol pollution has brought to the forefront. Hence, understanding the distributions and pollution sources of volatile phenol was essential, and meaningful to assess the its pollution level and environmental impact [1-2]. Based on the investigation data on volatile phenol in surface waters in different seasons in 1983, the aim of this paper was to analysis the content and spatio-temporal distribution of volatile phenol, to identify the pollution level, pollution source and source strength of volatile phenol, and to provide theoretical basis for management and remediation of volatile phenol pollution. 


\section{Materials and method}

Jiaozhou Bay $\left(35^{\circ} 55^{\prime}-36^{\circ} 18^{\prime} \mathrm{N}, 120^{\circ} 04^{\prime}-120^{\circ} 23^{\prime} \mathrm{E}\right)$ is located in the south of Shandong Peninsula, eastern China. It is a semi-closed natural bay, whose area, bay mouth width and average water depth and maximum water depth are $390 \mathrm{~km}^{2}, 2.5 \mathrm{~km}$ and $7 \mathrm{~m}$, respectively (Fig. 1). This bay is surrounding by cities of Qingdao, Jiaozhou and Jiaonan, respectively. There are more than ten inflow rivers, all of which are seasonal rivers [3].

The investigation on volatile phenol in nine sampling sites in Jiaozhou Bay waters was conducted by North China Sea Environmental Monitoring Center in May, September and October 1983 (Fig. 1). The measurement of these pollutants was follow by National Specification for Marine Monitoring [4].

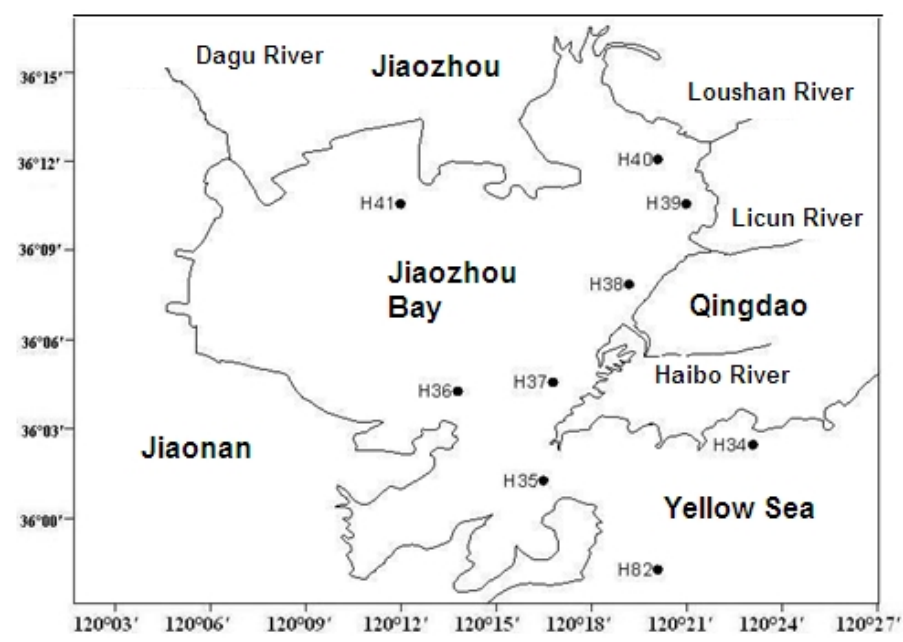

Fig.1 Geography location and sampling sites of Jiaozhou Bay

\section{Results and discussion}

Contents and pollution level. Volatile phenol contents in Jiaozhou Bay waters in May, September and October 1983 were ranged from $0.50-2.50 \mu \mathrm{g} \mathrm{L} \mathrm{L}^{-1}, 0.50-3.38 \mu \mathrm{g} \mathrm{L} \mathrm{L}^{-1}, 1.10-2.58 \mu \mathrm{g} \mathrm{L}^{-1}$, respectively, and were ranged from $0.50-3.38 \mu \mathrm{g} \mathrm{L}^{-1}$ in the whole year. In according to the guide line of Class I for volatile phenol $\left(5.00 \mu \mathrm{g} \mathrm{L}^{-1}\right)$ in National Standard of China for Seawater Quality (GB3097-1997), this bay was very slightly contaminated by volatile phenol in 1983.

Spatial distributions. In May, high value of volatile phenol was occurred in Site H37 $\left(1.75 \mu \mathrm{g} \mathrm{L}^{-1}\right)$, and there was a high value region in the coastal in the east, with a series of semi-concentric circles. The contents were decreasing from the high value center to $0.90 \mu \mathrm{g} \mathrm{L}^{-1}$ in the center waters in the bay (Fig. 2). The was also a high value center in Site $\mathrm{H} 82$ outside the bay $\left(2.50 \mu \mathrm{g} \mathrm{L}^{-1}\right)$, and were a series of different gradient parallel lines, indicating that volatile contents were decreasing from waters outside the bay to the waters inside the bay $\left(0.50 \mu \mathrm{g} \mathrm{L}^{-1}\right)$, along with the direction of marine current. In September, high value $\left(3.38 \mu \mathrm{g} \mathrm{L}^{-1}\right)$ of volatile phenol was occurred in Site H39 closed to the estuaries of Loushan River and Licun River. There was a high value region in the northeast, with a series of semi-concentric circles. The contents were decreasing from the high value center to $0.70 \mu \mathrm{g} \mathrm{L}^{-1}$ in the center waters in the bay (Fig.3). The was also a high value $\left(2.60 \mu \mathrm{g} \mathrm{L}^{-1}\right)$ center in Site H41 in coastal water in the north, with a series of different gradient parallel lines, indicating that volatile contents were decreasing from waters outside the bay to the bay mouth $\left(0.70 \mu \mathrm{g} \mathrm{L}^{-1}\right)$. 
There were three high value regions in October. The first high value of volatile phenol was occurred in Site H39 (3.38 $\left.\mu \mathrm{g} \mathrm{L}^{-1}\right)$, and there was a high value region in the coastal in the north, with a series of semi-concentric circles. The contents were decreasing from the high value center to $1.75 \mu \mathrm{g} \mathrm{L}^{-1}$ in the bay mouth (Fig. 4). The second high value was in Site H36 (2.25 $\left.\mu \mathrm{g} \mathrm{L}^{-1}\right)$, and was forming a high value region in the coastal waters in the southwest, with with a series of semi-concentric circles. The contents were decreasing from the high value center to $1.75 \mu \mathrm{g} \mathrm{L}^{-1}$ in the bay mouth (Fig. 4). The third high value center was in Site $\mathrm{H} 34$ outside the bay $\left(1.90 \mu \mathrm{g} \mathrm{L}^{-1}\right)$, and were a series of different gradient parallel lines, indicating that volatile contents were decreasing from waters outside the bay to the south $\left(1.10 \mu \mathrm{g} \mathrm{L}^{-1}\right)$.

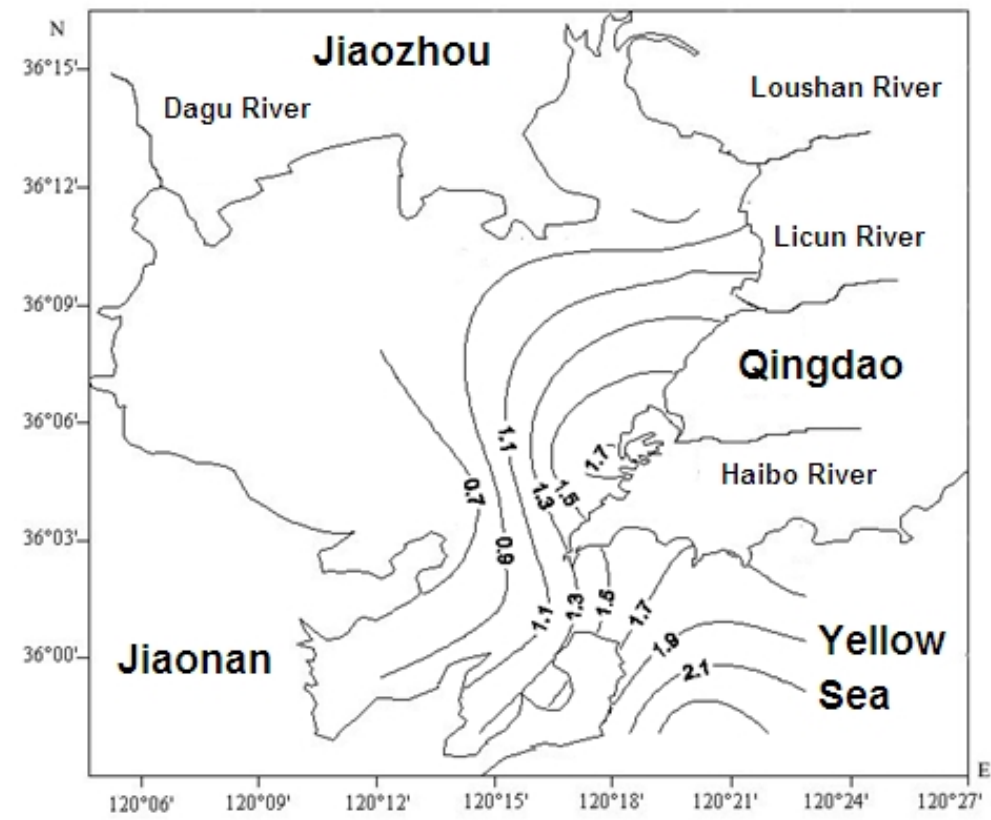

Fig. 2 Spatial distribution of volatile phenol in surface waters in Jiaozhou Bay in May 1983/ $\mu \mathrm{g} \mathrm{L}^{-1}$

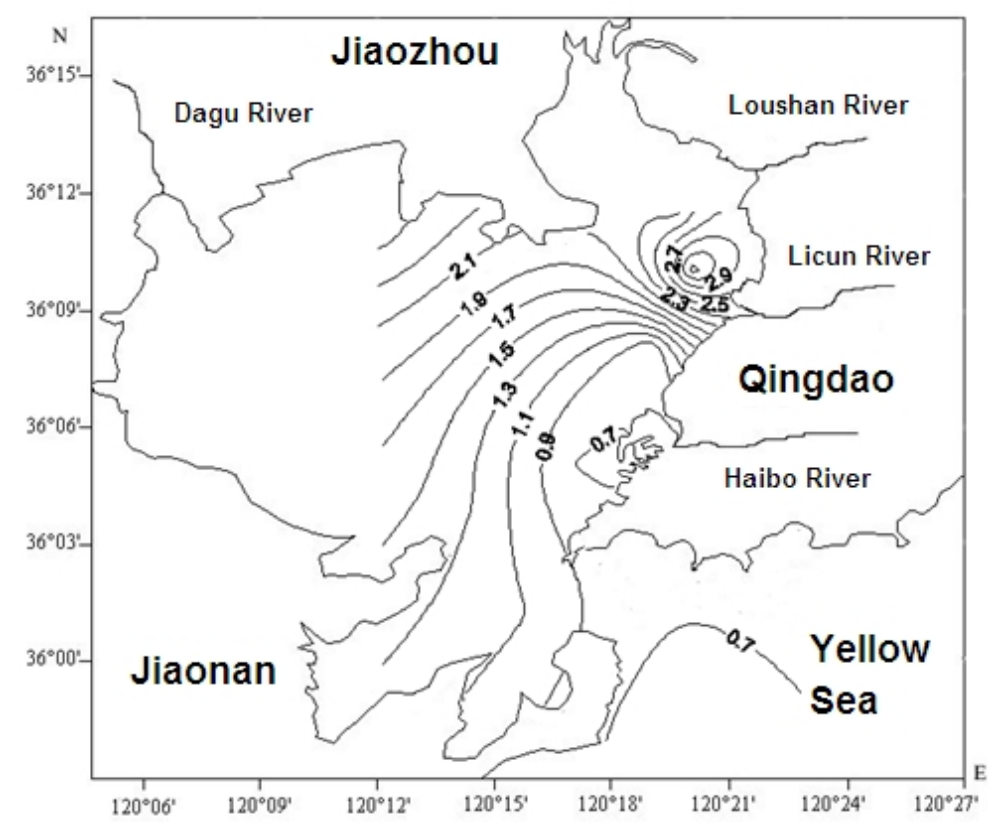

Fig. 3 Spatial distribution of volatile phenol in surface waters in Jiaozhou Bay in September $1983 / \mu \mathrm{g} \mathrm{L}{ }^{-1}$ 


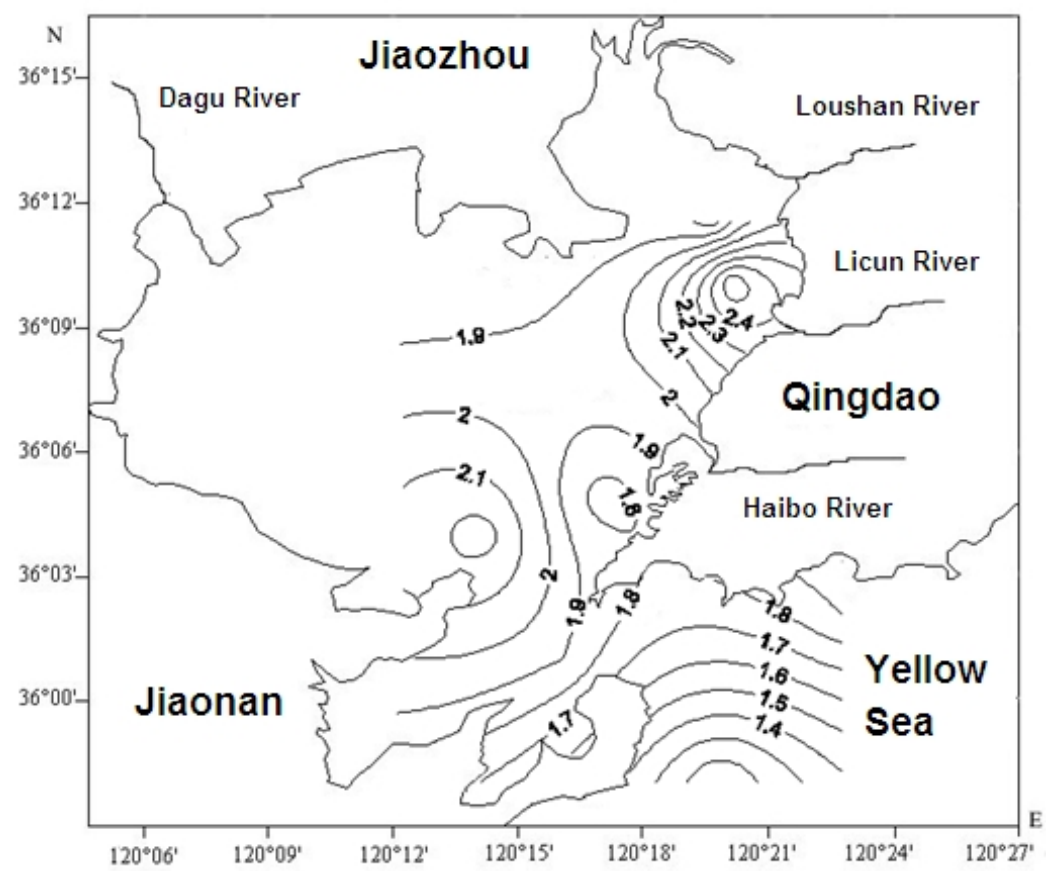

Fig. 4 Spatial distribution of volatile phenol in surface waters in Jiaozhou Bay in October 1983/ $\mu$ g $\mathrm{L}^{-1}$

Pollution sources and source strengths. In according to the spatial distributions, we found that there were some relative high value regions, including estuaries of the major rivers in the northeast, coastal areas in the east, north and southwest, as well as waters outside the bay mouth. Hence, it could be concluded that the major sources of volatile phenol were stream flow, overland flow inside the bay, overland flow outside the bay, marine current and marine terminals. In consideration with the high values in the high value regions, it could be seen that the source strengths of different pollution sources were different (Table 1). We defined marine current was natural source, while the other sources were anthropogenic sources, it was clear that the impacts from human activities were closed to sea water pollutant background in 1983.

Table 1 Source strengths of different pollution sources for volatile phenol in Jiaozhou bay

\begin{tabular}{|c|c|c|c|c|c|}
\hline \multirow[b]{2}{*}{ Source } & \multirow[b]{2}{*}{$\begin{array}{l}\text { River } \\
\text { flow }\end{array}$} & \multicolumn{2}{|c|}{ Overland flow } & \multirow[b]{2}{*}{$\begin{array}{l}\text { Marine } \\
\text { current }\end{array}$} & \multirow{2}{*}{$\begin{array}{c}\text { marine } \\
\text { terminals }\end{array}$} \\
\hline & & $\begin{array}{l}\text { Inside the } \\
\text { bay }\end{array}$ & $\begin{array}{l}\text { Outside the } \\
\text { bay }\end{array}$ & & \\
\hline Content/ $\mu \mathrm{g} \mathrm{L}^{-1}$ & $2.58-3.38$ & $2.25-2.60$ & 1.90 & 2.50 & 1.75 \\
\hline
\end{tabular}

\section{Conclusions}

Jiaozhou Bay was very slightly contaminated by volatile phenol in 1983 . The major sources of volatile phenol were stream flow, overland flow inside the bay, overland flow outside the bay, marine current and marine terminals, whose source strengths were 2.58-3.38 $\mu \mathrm{g} \mathrm{L}^{-1}, 2.25-2.60 \mu \mathrm{g}$ $\mathrm{L}^{-1}, 2.50 \mu \mathrm{g} \mathrm{L}^{-1}, 1.90 \mu \mathrm{g} \mathrm{L} \mathrm{L}^{-1}$ and $1.75 \mu \mathrm{g} \mathrm{L}{ }^{-1}$, respectively. Generally speaking, Jiaozhou Bay was very slightly contaminated by volatile phenol in 1983, and the impacts from human activities were 
closed to sea water pollutant background.

\section{Acknowledgement}

This research was sponsored by Doctoral Degree Construction Library of Guizhou Nationalities University, Education Ministry's New Century Excellent Talents Supporting Plan (NCET-12-0659), Education Ministry's New Century Excellent Talents Supporting Plan (NCET-12-0659), Project of Outstanding Technological Educators of Governor of Guizhou ([2012]71), Project of Low Carbon Technology Plan of Guiyang (2012205]), Project of Science and Technology Foundation of Guiyang (LKM[2012]05), Special Research Projects of High Level Talents of Guizhou Province (TZJF-2011-44), and Research Projects of Guizhou Nationalities University ([2014]02), Research Projects of Guizhou Province Ministry of Education (KY [2014] 266), Research Projects of Guizhou Province Ministry of Science and Technology (LH [2014] 7376).

\section{Reference}

[1] Yang DF, He HZ, Zhu SX, et al.:Materials, Environmental and Biological Engineering, (2015), pp. 343-346.

[2] Yang DF, He XH, Gao J, et al.: Materials, Environmental and Biological Engineering, (2015), pp.1103-1106.

[3] Yang DF, Chen Y, Gao ZH, et al.: Chinese Journal of Oceanology and Limnology, Vol. 23 (2005), pp. 72-90.

[4] State Ocean Administration. The specification for marine monitoring: Beijing, Ocean Precess, (1991). 